\title{
User Frames in Media Arts
}

\author{
Atıf Akın \\ 195 Chrystie St. \# 601D \\ New York, NY 10002, USA \\ www.paganstdio.com
}

\section{SUMMARY}

In 2009 I curated a large scope media art exhibition, 'Uncharted: User Frames in Media Arts' (Please follow the link for the video for a general view of the exhibition http://vimeo.com/13642152). Back then I was commissioned to make this media arts research focused on user participation and interaction and to organize the exhibition. I already met with many artists at various festivals and joint exhibitions where I was also showing my works. They were all dealing with digital media and interaction design. I had a vague idea to put things together around the physical engagement of the visitors, heavily inspired by cyberculture of the late 80 's. Furthermore the name of the exhibition is taken from an interview by William Gibson where he was talking about his book titled 'Neuromancer' and he says '... there are no maps for these territories...' However this pseudo-romantic cybercultural approach was fun and helped to shape the visual identity and provided some promotion ideas but it was totally useless to guide me in the process when it comes to installing pieces in the gallery space. That's why I had the urge to explore a new idea, a theory in humanmachine interaction which would guide me through and help me to make meaningful aesthetic decisions during installation process.

Stylistically, inspirations from German Expressionism are not new today. Prominent example for this would be Ridley Scott's 1982 film Blade Runner, which was itself influenced by Metropolis. In search of a new theory I was inspired by a film by Walter Ruttmann, Berlin: Symphony of a Great City and a book by French philosopher Jacques Derrida, The Truth in Painting. Watching the film Berlin: Symphony of a Great City (German: Berlin: Die Sinfonie der Großstadt) we can see that the Germans loved to work or they liked watching man at work. Throughout the film, figures of men are seen working with their hands on machines, steel forging, doing physical exercises, they are all active and participated to things at different aspects of life. These compositions of working men are exalted and glorified and this workthrough is overwhelmingly emphasized. Man and machine merged into a whole-created one of the most important icons of German National Socialist aesthetics. Wagner transformed musical thought through his idea of Gesamtkunstwerk (total work of art), the synthesis of the poetic, visual, musical and dramatic arts, epitomized by his monumental fouropera cycle Der Ring des Nibelungen (1876). This translated into Beuys's formulation of the idea of Social Sculpture (Sozial Plastik): Society as a whole is to be regarded as one great work of art (the Wagnerian Gesamtkunstwerk) to which each person can contribute creatively (possibly, Beuys's most famous phrase, borrowed from Novalis, is "Everyone is an artist"). In his famous book The Truth in Painting, French philosopher Jacques Derrida considers the 'frame' to be a parergon. Derrida writes about painting and the notion of frame in terms of the image and the canvas. According to Derrida, the outside always comes into the inside in order to define itself as an inside. Nevertheless, his approach to the frame and its definition can be applied to the cybernetic context to define the user frames in media arts. I had the idea of considering that the visitor in the gallery space, who is in interaction with the artworks are the outsiders in the first circle of the work who are trying to be insiders and complete the frame to constitute a parergon.

The glorified imagery of men at work, which is backed up by the idea of national socialist working class identity and ethics is, today, more than ever, constantly being mimicked in everyday life, turning human to post-human totally wired and signaled with various digital gadgets in everyday life. This glorification and identification of this 'busy' posthuman is performed in the context of interactive media arts. As digital programming techniques and supporting digital technologies are becoming more available to artists, more they produce interactive artworks which are assumed to act as an artwork only if there is a user to frame it. I believe Derrida's parergon and the repercussions alter this definition will be quite useful to study this phenomenon. 
My ongoing doctoral research is about combining the first idea with the second definition to scrutinize the sculptural quality of the viewer, as the artwork itself, for the a solid theory of interactive art works, in relation to social politics, in the context of media arts. The research is particularly focused in gallery space.

\section{REFERENCES}

Derrida, J. (2011) The Truth in Painting - essay \#1

Rogowski, C. (2011) The Many Faces of Weimar:

Cinema Rediscovering Germany's Filmic Legacy

Ruttmann, W. (1927) Berlin: Symphony of a Metropolis 